\title{
The Parasitic Mites of Birds, a Contribution to the Knowledge of the
} Sarcoptidæ. By E. Ehlers.

The observations of M. Ehlers, which relate to interesting questions of adaptation and heredity, are made upon an Acarian very nearly allied to that described by M. C. Robin under the name of Sarcoptes mutans. It is also a bird-parasite, and was discovered on a specimen of Munia maja, in which it produced excrescences at the base of the beak. For this species and M. Robin's the author establishes the genus Dermatoryctes, which is particularly characterized by the form of the feet in the two sexes. He calls his species Dermatoryctes fossor.

The female of $D$. fossor is much larger than the male, and also very different in form. It is incapable of moving outside the galleries which it inhabits, partly because it is encumbered by the large eggrs which it carries in its body, and partly because it cannot touch the ground with its feet. These (which are extremely short) present an epimeron, a coxa, and leg formed of three joints, the terminal joint being a sort of quadridentate clasper, probably homologous with the two joints which are distinct in $D$. mutans, and which M. Robin calls tibia and tarsus.

The males are smaller and much more active, and also less numerous, than the females. Their body is contracted in front and behind; their legs are much longer than those of the females, and differently constructed; in particular, they bear long hairs, and each of them has a sucker with a long pedicle on its terminal joint.

M. Ehlers was unable to ascertain whether this Acarian is oviparous or viviparous. He supposes that the membrane of the egg becomes much attenuated at the close of the development, and that the embryo is born after having got free from it, or that this membrane is ruptured during the birth.

In the first period of their life the young Acarians run easily by means of their three pairs of legs, which are long and very like those of the adult males; each of them bears at its extremity a sucker with a long pedicle, and five hairs, the longest of which exceeds the sucker.

The transformations through which the animal afterwards passes are the results of a certain number of moults, which must be regarded as being more than mere changes of skin. During these moults the mite remains in a state of immobility and rigidity, which seems to indicate that we have to do with a true case of nymphosis, accompanied by new formations analogous to those observed by Weissman in the metamorphoses of insects. Küchenmeister had previously witnessed phenomena of this kind in Sarcoptes scabiei, and Claparède has described in detail the manner in which a new development takes place in the interior of the old skin in Atax and Hoplophora. Matters appear to go on in an analogous fashion in the species observed by M. Ehlers, although this naturalist was unable to ascertain positively that complete histolysis takes place. 
There are remarkable differences between the development of the male and of the female. The male undergoes no profound changes in passing from the larval to the adult state. In these two phases of its existence it presents the same peculiarities of structure. Its structure perfectly resembles that which we observe in the Sarcoptidæ in general, in which the legs bear long hairs, and some of them, if not all, have also pedunculated suckers. The characteristics of the family which exist in the young persist in the male until the adult state.

In the females it is otherwise. The changes which take place in the course of development give rise not only to differences which characterize the adult, but also to arrangements which are not met with in other Sarcoptidæ.

At the last moult but one the female appears with its eight legs, its genital aperture, and all its other principal characters. It is then only distinguished from the adult by its not yet having ova in its body, and by the dorsal shield only presenting pointed, conical protuberances, instead of the flattened scales which this region exhibits in the adult. After increasing in bulk it undergoes another moult in order to attain its definitive condition, in which the dorsal surface is covered with flattened scales. These protuberances, which are in themselves of but little importance, are interesting because they also appear in the mites of the genus Sarcoptes, in which they are particularly developed in the female sex. In the species of which the adult females do not present these projections, they are also wanting in the male; in Sarcoptes scabiei they are found not only in the adult female, but also, although much less developed, in the male. In Dermatoryctes fossor they are exclusively characteristic of the female. M. Ehlers thinks that this formation of the skin may have been originally a secondary sexual character of the females which has become a little attenuated in the species under consideration, whilst in other female Sarcoptidæ it has maintained itself and even been transmitted to the males by heredity.

The legs of the females undergo remarkable transformations at the last moult; they become short stumps which have lost a joint, and no longer possess hairs or suckers. The Sarcoptidæ of the Mammalia present a similar modification, although far less profound; for the females have their last two pairs of legs destitute of suckers, whilst the males possess them at least on the last pair but one. On the other hand, in Dermatophagus and Dermatokoptes (Fürst.) the female has a sucker at least in one of the posterior pairs of feet, and in the male we find one on each foot; this fact is the more remarkable because in these genera the sucker does not exist in the larval state, and only appears at the last change of skin. The two genera in question differ from the true Sarcoptes in not piercing canals in the epidermis of their host, but living more on the surface, concealed by the hairs, the cells detached from the epidermis, \&c. The disappearance of the suckers and the shortening of the legs consequently seems, in the Sarcoptes, to be in connexion with the mode of life, and especially with the nature of the habitat; so that those which 
require to form galleries undergo the greatest abbreviation of the legs, which must have been influenced especially by the comparative disuse of those organs.

The female of $D$. fossor lives at the extremity of a straight gallery, which it completely fills. Under such conditions its short, strong legs are very useful to it in progressing after the fashion of a mole, by pressing obliquely against the walls of the gallery, so as to push the animal forward. Outside the gallery these legs could be of no use to it. The young females and the males, on the contrary, can move in galleries which are as it were too large for them.

The rectilinear direction and the small size of the galleries is explained by the hardness of the horny substance of the beak in which they are pierced, which causes the animals to confine themselves to a straight passage, having exactly the calibre of their bodies. In the Mammalia, the epidermis of which forms a less resistant tissue, the passages are tortuous, increase gradually in depth, and offer more space to the mites than is afforded to the parasite of the bird's beak. -Zeitschr. für wissenschaftl. Zoologie, vol. xxiii. pp. 228-253; Bibl. Univ. July 15, 1873, Bull. Sci. pp. 244-247.

\section{Contributions to the Knowledge of the Laboulbeniæ. By Dr. J. Peyritsch.}

The author describes the mode of occurrence and the development of these parasitic fungi. Hitherto only five species of Laboulbenice were known, three of which were observed on beetles. New species have been detected on Carabidæ, Staphylinidæ, and Dytiscidæ. By their development, and especially the process of fecundation, the Laboulbenice approach the other Ascomycetes; fecundation takes place by the contact of delicate, filiform organs, pollinodia and trichogynæ. The pollinodia are developed at the terminal part of the young plant upon peculiar bearers, the form of which is characteristic of the species; the trichogyne terminates the rudiment of the fruit. In some species the latter is a delicate filament of several joints; but in Laboulbenia muscce it is unicellular; in all species it is thrown off after fecundation. The fruit is only developed after fecundation ; it opens by an apical pore and allows the spores to escape. The spores are produced in diverticula of one (or several?) cell in a series of cells, the upper extremity of which previously formed the trichogyne. The form and insertion of the bearer of the pollinodia and its appendicular structures, and the form of the armature of the mouth of the fruit, furnish the most important characters for distinguishing the species of this small group of fungi. Dr. Peyritsch's memoir contains descriptions of all the species, which are referred to five genera.-Anzeiger der Akad. der Wiss. in Wien, October 23, 1873. 


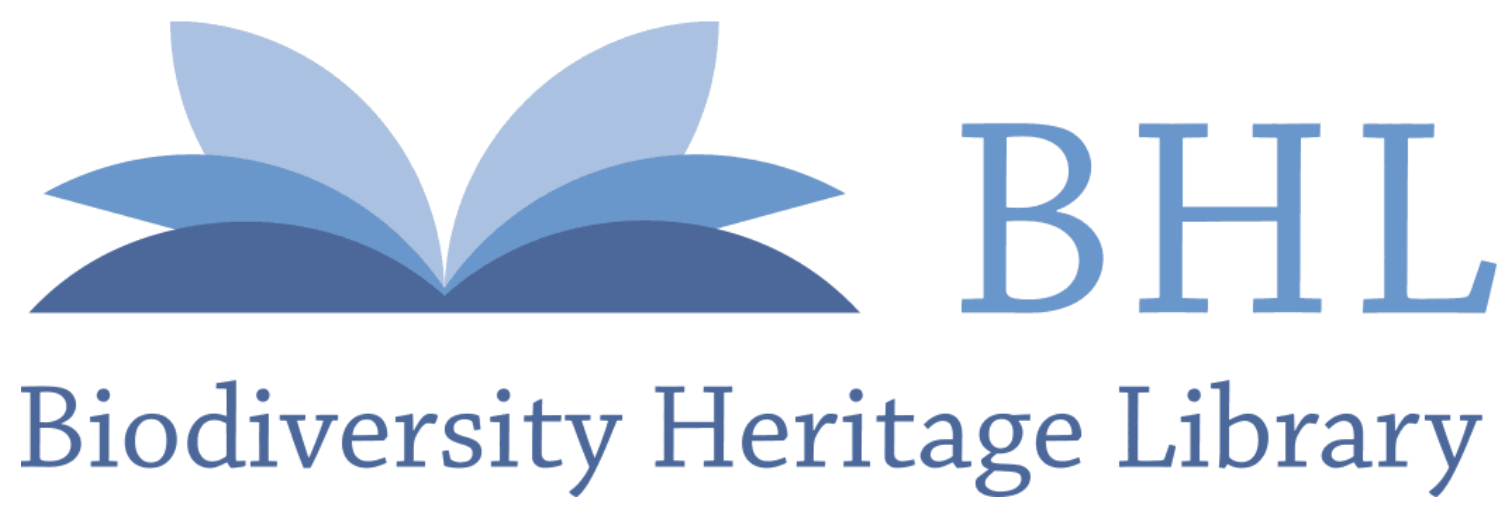

Ehlers, Ernst Heinrich. 1874. "The parasitic mites of birds, a contribution to the knowledge of the Sarcoptidæ." The Annals and magazine of natural history; zoology, botany, and geology 13, 74-76.

https://doi.org/10.1080/00222937408562440.

View This Item Online: https://www.biodiversitylibrary.org/item/78506

DOI: https://doi.org/10.1080/00222937408562440

Permalink: https://www.biodiversitylibrary.org/partpdf/62132

\section{Holding Institution}

University of Toronto - Gerstein Science Information Centre

\section{Sponsored by}

University of Toronto

\section{Copyright \& Reuse}

Copyright Status: NOT_IN_COPYRIGHT

This document was created from content at the Biodiversity Heritage Library, the world's largest open access digital library for biodiversity literature and archives. Visit BHL at https://www.biodiversitylibrary.org. 